УДК 347.152

DOI https://doi.org/10.32837/pyuv.v1i3(28).325

\author{
В. В. Васильєе \\ кандидат юридичних наук, \\ доиент кафедри иивільно-правових дисииплін \\ Східноєвропейського національного університету ілені Лесі Українки, \\ докторант кафедри иивільного права № 2 \\ Національного юридичного університету імені Ярослава Мудрого
}

\title{
ЗВИЧАЙ ЯК ПРАВОВИЙ ЗАСІБ САМОРЕГУЛЮВАННЯ МАЙНОВИХ ЦИВІЛЬНИХ ВІДНОСИН У СУЧАСНИХ УМОВАХ
}

Набуття правовим звичаєм ролі головного засобу регулювання майнових відносин на ранніх стадіях розвитку держави було невідворотним. Тривалий час формування відповідних правил поведінки надало їм стійкого характеру, а джерело їх походження, яким виступили безпосередньо учасники правовідносин, які практикою правореалізації сформували відповідні норми, а по суті народ, зумовило загальновизнаний i загальноприйнятий характер відповідних правил. За таких умов на ранніх стадіях розвитку державні утворення не могли здійснювати кардинальні зміни у характері упорядкування суспільних зв'язків з приводу майнових благ. Як результат, основні звичаї отримали визнання з боку влади, а сам звичай продовжив слугувати основним засобом регулювання майнових відносин.

Поряд із цим специфіка формування звичаю позбавляла його оперативності в реагуванні на вимоги суспільства. Ця якість багато в чому визначила перевагу нормативно-правових актів над звичаями як джерелами права і засобами правового регулювання майнових відносин, що сприяло посиленню примату централізованого регулювання, в тому числі приватних відносин, над децентралізованим.

Положення чинного Цивільного кодексу України (далі - ЦК України) також визначають звичай одним із джерел вітчизняного цивільного права (ст. 7), однак його справжня інструментальна природа в контексті сучасного механізму цивільно-правового регулювання суспільних відносин залишається до кінця нерозкритою, що і зумовлює актуальність розгляду порушеної проблеми.

Сутність та засоби регулювання приватних відносин ставали предметом наукових досліджень таких учених-правників, як В.К. Антошкіна, B.I. Борисова, Б. Віндшейд, О.М. Гончаренко, Д.Д. Грімм, Г. Дернбург, М.Ф. Казанцев, Л.А. Корунчак, В. В. Кочин, Н.С. Кузнєцова, Р.А. Майданик, І.В. Спасибо-Фатєєва, В.С. Толстой, Б.Б. Черепахін, В.Л. Яроцький та ін.

Мета статті полягає у визначенні особливостей правового звичаю як засобу саморегулювання майнових цивільних відносин в Україні в сучас- них умовах і його місця в системі інструментів упорядкування відповідних суспільних зв'язків.

В аспекті порушеної проблеми ключовим положенням виступає ст. 7 ЦК України.

Визначення звичаю міститься в абз. 2 ч. 1 наведеної статті, відповідно до якої звичаєм є правило поведінки, яке не встановлене актами цивільного законодавства, але є усталеним у певній сфері цивільних відносин [1, ст. 7].

Це нормативне положення визначає дві ознаки правового звичаю як засобу правового регулювання, зокрема майнових цивільних відносин: 1) невстановленість законом; 2) усталеність у певній сфері цивільних відносин.

Що стосується невстановленості законол, то ця ознака правового звичаю знаходить розкриття у двох аспектах. Перший полягає у порядку формування правового звичаю. $\mathrm{y}$ цьому сенсі процес утворення звичаю як правового інструменту упорядкування майнових цивільних відносин зумовлює його віднесення до засобів саморегулювання. На стадії його утворення відповідне правило поведінки встановлюється і приймається учасниками правовідносин самостійно, що, своєю чергою, є результатом спільного узгодження воль відповідних осіб.

При цьому одним зі способів формування правового звичаю може виступати багаторазове встановлення відповідного правила поведінки в рамках певної моделі правовідносин їх учасниками на рівні домовленостей, тобто договору, що демонструє вплив практики індивідуального регулювання суспільних відносин на встановлення загальнообов'язкових правил нормативного характеру.

Другий аспект наведеної ознаки конкретизує форму існування правового звичаю. Як відомо, на ранніх стадіях розвитку державних утворень саме звичаї, санкціоновані державою, виступали першими правовими засобами регулювання суспільних відносин. Однак у такому разі постає проблема співвідношення між звичаєм i нормативно-правовим актом в аспекті форми ïx фіксації i існування. Зокрема, як зазначає H.M. Пархоменко, звичаєво-правові норми не мають формальної визначеності, за винятком 
випадків запису їхнього змісту в тексті закону, судового рішення та ін. Але зафіксоване таким чином правило перестає ідентифікуватись як звичай [2, с. 9]. Таким чином, одночасне існування звичаю і нормативно-правового акта як регуляторів майнових цивільних відносин є цілком можливим, хоча форми їх існування можуть бути взаємовиключними. Фіксація звичаєвого положення на рівні нормативно-правового акта перетворює його на положення цього акта. У зв'язку з цим видається, що на рівні положень нормативно-правових актів може фіксуватись, наприклад, сфера застосування звичаїв (торговельні звичаї, сімейні звичаї тощо) або окреслюватись питання, які вирішуються звичаєм, наприклад, розмір оплати посередницьких послуг, однак не сама звичаєва норма.

У зазначеному ракурсі інтерес викликає нормативне положення, закріплене в абз. 3 ч. 1 ст. 7 ЦК України, відповідно до якого звичай може бути зафіксований у відповідному документі [1, ст. 7]. По суті, воно припускає, що звичаєва норма все ж таки може бути документально зафіксована, однак з урахуванням абз. 2 ч. 1 наведеної статті ЦК України відповідний документ не має бути актом цивільного законодавства. Як зазначає з цього приводу Н.С. Кузнєцова, найбільш поширеними є зібрання торговельних звичаїв, що застосовуються у міжнародному торговельному обороті.

Одним з найбільш авторитетних зібрань міжнародних торговельних звичаїв є Правила «ІНКОTEPMC», що уточнюються та редагуються Міжнародною Торговельною Палатою у Парижі (ICC) [3, с. 23$]$.

Викладене вище дає змогу стверджувати, що звичаєва норма і положення нормативно-правового акта, як правило, мають різну форму існування. Звичаєва норма може існувати незалежно від її документальної фіксації, тоді як однією з визначальних ознак положення нормативно-правового акта є його фіксація в тексті такого акта, форма якого визначається законом і конкретизується специфічними ознаками, зокрема реквізитами. При цьому фіксація звичаєвої норми може бути здійснена в документі. Однак якщо такий документ має ознаки нормативно-правового акта, то відповідна норма втрачає характер звичаєвої і стає положенням відповідного акта.

Другою ознакою звичаю як джерела цивільного права, що визначена положеннями ЦК України, виступає усталеність.

Характеризуючись певною мірою оціночною категорією, ця ознака не знаходить чіткого розкриття в положеннях чинного цивільного законодавства України, у зв'язку з чим стає предметом аналізу науки цивільного права. 3 цього приводу в сучасній юридичній літературі зазначається, що усталеність звичаю як джерела цивільного права означає, що відповідне правило поведінки має застосовуватись у практиці протягом певного часу. При цьому таке правило має бути складеним у колі певних учасників цивільного обороту. Відповідна норма має бути одноманітною і однаковим чином сприйматись відповідними фізичними і юридичними особами [4, с. 88].

Загалом категорія "усталеність», відносячись до темпоральної понятійно-категоріальної сфери, має дуже умовний характер, що значно ускладнює ідентифікацію правила як звичаєвої норми. При цьому також необхідно враховувати і те, що усталеність характеризує часовий компонент, однак, як правило, мислиться у відриві від певної території. Це породжує проблеми територіальності поширення звичаю. Зокрема, чи може правило поведінки, яке знайшло поширення і є «усталеним» у певній частині країни, вважатись джерелом права i засобом правового регулювання майнових цивільних відносин? У разі схвальної відповіді на це питання $є$ необхідність визначення порядку поширення відповідного звичаю на учасників правовідносин, які не є постійними мешканцями території, де склався відповідний звичай, або місцезнаходження яких розташоване за межами таких територій. Іншими словами, визнання звичаями, хоча і усталених, однак локальних правил поведінки, створює передумови для диференціації джерел цивільного права як таких, що діють або на всій території України, або лише на окремих її частинах.

У контексті зазначеного слід констатувати, що в положеннях чинного цивільного законодавства України, як правило, уникається відповідна диференціація. Як приклад можна навести ч. 4 ст. 632 ЦК України, відповідно до якої, якщо ціна у договорі не встановлена і не може бути визначена виходячи з його умов, вона визначається виходячи зі звичайних цін, що склалися на аналогічні товари, роботи або послуги на момент укладення договору [1, ст. 632]. Хоча, зважаючи на те, що ціни на окремі товари роботи і послуги якраз диференціюються залежно від регіону, більш обгрунтованою виглядає позиція, згідно з якої такі ціни все ж таки визначаються в контексті території вчинення правочину або виконання відповідних дій, зокрема з надання послуг або виконання робіт, якщо інше не встановлено законом або договором. Однак це певною мірою ставить у невигідне положення особу, яка може бути не обізнана щодо відповідних цін у визначеному регіоні, зокрема внутрішньо переміщених осіб.

Виняток становлять лише окремі положення, зокрема абз. 3 ч. 3 ст. 1197 ЦК України, яким встановлюється, що у разі, якщо потерпілий на момент завдання йому шкоди не працював, його середньомісячний заробіток (дохід) обчислюється, за його бажанням, виходячи з його заробітку до звільнення або звичайного розміру заробітної 
плати працівника його кваліфікації у цій місцевості [1, ст. 1197].

Для того щоб зрозуміти, які саме правила поведінки становлять правові звичаї і дати відповіді на порушене питання, необхідно звернутись до відповідних прикладів. Норми такого типу, зокрема в територіальному аспекті, наводились Д.І. Мейером, який досить багато уваги присвятив аналізу торговельного побуту Одеси. За результатами спостережень учений відзначив декілька досить цікавих звичаєвих правил.

Зокрема, цікавим був правовий звичай, згідно 3 яким у разі відсутності домовленості комісіонера і комітента щодо розміру винагороди, відповідно до звичаю в Одесі, комісіонер має право на $2 \%$ від оборотного капіталу за купівлю або продажу і $1 \%$ за відправку чи приймання товарів. При цьому вчений зазначає, що за загальним правилом розмір винагороди встановлюється сторонами на підставі договору, однак у такому разі вони все одно, як правило, звертаються до звичаю. Проте траплялись і випадки, коли суд, незважаючи на досягнені домовленості у вирішенні спору, застосовував звичай [5, с. 176]. 3 цього видається, що звичай міг мати перевагу над договором у частині регулювання майнових цивільних відносин. При цьому важливо, що наведені приклади демонструють те, що територіальна сфера формування і застосування звичаєвої норми могла мати обмежений характер, тобто обмежувалась певною територією країни.

Таким чином, ми підходимо до проблеми місця звичаю в системі правових засобів регулювання майнових цивільних відносин у сучасних умовах. В аспекті аналізованого нормативного положення, тобто ст. 7 ЦК України, цій проблемі присвячена завершальна частина відповідного припису, зокрема ч. 2, якою встановлюється, що звичай, що суперечить договору або актам иивільного законодавства, у иивільних відносинах не застосовується [1, ст. 7].

Важливість цього положення в умовах сьогодення має принциповий характер і полягає в тому, що цим приписом фактично запроваджується примат актів цивільного законодавства як правових засобів централізованого регулювання майнових цивільних відносин і договору як правового засобу децентралізованого регулювання майнових цивільних відносин (саморегулювання) над звичаєм.

При цьому твердження про те, що «звичай, що суперечить договору, у иивільних відносинах не застосовується" фактично запроваджує диспозитивний характер звичаю стосовно договірного регулювання. Буквально це означає, що договір може слугувати правовим засобом нівелювання будь-якого звичаю, що значно ослаблює стабільність класифікаційного критерію поділу звича- їв на диспозитивні й імперативні. 3 аналізованої норми вбачається, що стосовно договору презумується диспозитивність звичаєвої норми, оскільки обов'язковість останньої для застосування у договірних відносинах може нівелюватись домовленістю учасників відповідних правовідносин.

Аналізований припис довершує наукову картину розуміння сутності правового звичаю і його інструментального потенціалу в умовах сьогодення, а також аспекти еволюції в процесі розвитку інструментів правового регулювання суспільних відносин загалом. Хоча слід відзначити, що порушена проблема актуалізувалась ще у XIX ст. і стала предметом розгляду, зокрема, німецьких учених-пандектистів. 3 цього приводу Б. Віндшейд зазначав, що чим більше розвивається законодавство, тим більше відтісняє воно на задній план звичаєве право; чим більш розвинутими стають відносини, тим складнішим стає утворення юридичного переконання, що охоплює весь народ; звичаєве право переміщається в більш тісні народні кола, у географічні або професійні, або ж набуває опосередковану форму права юристів. У зв'язку з чим учений констатував, що законодавство стало найважливішим, однак далеко не першим джерелом права [6, с. 39]. Своєю чергою Г. Дернбург відзначав, що багато хто схильний бачити в законі єдине нормальне джерело права й сумніваються в законності існування звичаєвого права. Це формує потребу у пошуку для звичаєвого права внутрішніх підстав і тим самим ніби захистити його. Вчиняються спроби довести його рівноправність із законом і для цього обидва джерела приводяться до єдиного першоджерела. Так робили римські юристи часів імперії. На їхнє переконання, народна воля виступає підставою права. У зв'язку з цим не важливо чи виявляє народ свою волю посередництвом голосування або шляхом звичаю. При цьому вчений зазначає, що в новий час до цього питання підходили з іншого боку. У XVIII ст. часто лише в законах вбачали єдине нормальне джерело права. Своєю чергою звичаєве право набувало значення тільки через мовчазне «схвалення» законодавця. Історична школа повстала проти такого погляду. Визнаючи за народним переконанням обов'язкову силу, вона виводила з нього як звичай, так і закон. У звичаї народне переконання відображається безпосередньо, а в законі - опосередковано [7, с. 66-67].

При цьому, як вбачається зі спостережень Д.I. Мейера, ще у XIX ст. практика щодо співвідношення положень договору і звичаєвих норм, зокрема на території Одеси, не була однозначною i в окремих випадках юридична сила останніх визначалась як більша, ніж у договору в контексті колізійного регулювання майнових відносин. Можна припустити, що така ситуація мала місце на території всієї держави. 
$\mathrm{y}$ сучасних умовах викладені вище обставини дають привід для обгрунтованого твердження, що сфера застосування звичаю як правового засобу регулювання цивільних відносин загалом є вкрай вузькою.

Проведений аналіз правового звичаю як засобу саморегулювання майнових цивільних відносин дає змогу дати відповідь на питання причин, з якими пов'язаний сучасний, у тому числі нормативний, підхід до його інструментального значення.

Одним з основних зовнішніх факторів, який послугував зменшенню інструментального значення звичаю в сучасних умовах, виступив розвиток майнових відносин, який втілився, зокрема, в пришвидшенні темпів цивільного обороту, а також прискореній еволюції об'єктів цивільних прав, різного роду юридичних конструкцій тощо. $\mathrm{У}$ таких умовах в учасників цивільних правовідносин виникае запит на гнучкі засоби упорядкування суспільних зв'язків, які відповідають індивідуальним потребам і індивідуальності юридичних ситуацій, в яких вони застосовуються, а на суб'єктів процесу нормотворення покладається обов'язок створення нормативного базису із забезпечення суб'єктивних цивільних прав і інтересів учасників відповідних правовідносин, суспільства й держави в швидкоплинному процесі еволюції.

Зазначеному фактору кореспондуе сутнісна властивість звичаю, яку можна назвати внутрішнім стримуючим фактором його адаптації до нових вимог суспільства і якою є низький рівень гнучкості звичаю як засобу регулювання майнових цивільних відносин, що в умовах змін спричиняє підвищення ризику невідповідності потребам правової і економічної реальності.

На тлі наведених обставин ваги набуває договір як найбільш адаптивний і універсальний інструмент упорядкування суспільних зв'язків, інші засоби індивідуального саморегулювання цивільних відносин, зокрема односторонні акти, а також нормативно-правовий акт як найбільш ефективний інструмент централізованого правового регулювання суспільних відносин, незмінність якого через необхідність відповідати сьогоденним потребам суспільства може бути досить нетривалою.

Через зазначені обставини відхід звичаю на другий план стало певною мірою закономірним результатом розвитку цивільного права. 3 урахуванням темпів розвитку суспільних відносин звичай елементарно не має шансів бути сформованим у певних сферах суспільних зв'язків, не говорячи про те, що ідентифікація звичаєвих норм у практиці правозастосування через порядок їх формування і форми існування є вкрай складною.

\section{Jimepamypa}

1. Цивільний кодекс України : Закон України від 16.01.2003 р. № 435-IV. Відом. Верхов. Ради України. 2003. №№ 40-44. Ст. 356 (із змінами).
2. Пархоменко Н.М. «Формальність» у праві: до аналізу проблеми. Часопис Київ. ун-ту права. 2007. № 1. С. $7-11$.

3. Науково-практичний коментар Цивільного кодексу України: у 2 т. / Кузнецова Н.С., Дзера О.В., Коссак В.М. та ін. ; за ред. О.В. Дзери (кер. авт. кол.), Н.С. Кузнєцової, В.В. Луця. 4-те вид., перероб. і допов. Київ : Юрінком Інтер, 2011. Т. 1. 808 с.

4. Вакула А.М., Парковская М.И. Обычай в гражданском праве: признаки и классификация. ЮристьПравоведй, 2015. № 6 (73). С. 87-90.

5. Мейер Д.И. Избранные произведения по гражданскому праву. Москва : АО «Центр ЮрИнфоР», 2003. $389 \mathrm{c}$.

6. Виндшейд Б. Учебник пандектного права: в 3 т. / пер. с нем. под. ред. С.В. Пахмана. СанктПетербург : Изд. Иероглифова и Никифорова, 1874. T. 1: Общая часть. XIV, 358 c.

7. Дернбург Г. Пандекты: в 3 т. / пер. Г. фон Рехенберга под. рук. П. Соколовского. Москва : Университет. типогр., Страстной бульвар, 1906. Т. I: Общая часть. XVI, 465 c.

\section{Анотація}

Васильєв В. В. Звичай як правовий засіб саморегулювання майнових цивільних відносин у сучасних умовах. - Стаття.

Стаття присвячена розгляду особливостей правового звичаю як засобу саморегулювання майнових цивільних відносин в Україні в сучасних умовах і визначенню його місця в системі інструментів упорядкування відповідних суспільних зв'язків.

Автор піддає глибокому осмисленню нормативні положення, закріплені в ст. 7 ЦК України, в яких відображається сучасне законодавче бачення інструментального потенціалу звичаю як правового засобу саморегулювання майнових цивільних відносин. Визначаються основні ознаки звичаю якими, зокрема, є: 1) невстановленість законом; 2) усталеність у певній сфері цивільних відносин.

Об'рунтовується, що невстановленість законом як ознака правового звичаю знаходить розкриття у двох аспектах. Перший полягає у порядку формування правового звичаю. У ході його утворення відповідне правило поведінки встановлюється і приймається учасниками правовідносин самостійно, що, своєю чергою, є результатом спільного узгодження воль відповідних осіб. Другий аспект наведеної ознаки конкретизує форму існування правового звичаю. Звичаєва норма, як правило, існує у незадокументованій формі, хоча і може фіксуватись у певних документах. Однак у разі їі фіксації в нормативно-правовому акті вона стає нормативним положенням і втрачає ознаки звичаю.

Визначається, що маючи оціночний характер «усталеність» як ознака правового звичаю не знаходить чіткого розкриття в положеннях чинного цивільного законодавства України, що породжує додаткові складнощі в ідентифікації правила поведінки як звичаю.

Автор констатує, що на тлі слабкої гнучкості правового звичаю як засобу регулювання суспільних відносин ваги набуває договір і односторонні акти як засоби саморегулювання майнових цивільних відносин, а також нормативно-правовий акт як інструмент їх централізованого регулювання. Відповідний підхід знайшов відображення в ст. 7 ЦК України.

Ключові слова: правовий звичай, саморегулювання, самоорганізація, договір, акти одностороннього характеру, майнові відносини. 


\section{Summary}

Vasyliev $V . V$. Legal custom as mean of self-regulation of proprietary civil relationships in the current context. - Article.

The article is devoted to consideration features of legal custom as mean of self-regulation of proprietary civil relationships in Ukraine in the current context and to determination its place in system of legal instruments of managing appropriate social relationships.

The author deeply comprehends the normative provisions fixed in Art. 7 of Civil Code of Ukraine, which display modern legislative assessment of instrumental potential of legal custom as legal mean of self-regulation of proprietary civil relationships. It's defined the main signs of legal custom that are: 1) non-fixation by legislative acts; 2) well-established character in defined sphere of civil relationships.

It's justified that non-fixation by legislative acts as sign of legal custom can be disclosed in two aspects. The first is the order of establishing appropriate practice. Its formation lies in practice of establishing and acceptation of appropriate rule by participants of civil legal relationship by themselves in particular by cooperative matching of wills. The second aspect concretizes form of existence of legal custom. It's determined that practice rule usually exists in undocumented form but can be fixed in documents. But fixation of rules of legal custom in legislative act transforms them to legislative provisions so they lose their customary character.

It's defined that having assessed character "well-established" as sign of legal custom is not disclosed by current legislative provisions of Ukraine and thus generates additional problems in practice of identification legal customs.

The author states that in connection with poor flexibility of legal custom as mean of self-regulation of social relationships a contract and unilateral acts as means of self-regulation of proprietary civil relationships and legal act as instrument of centralized regulation became more valuable. Appropriate approach is displayed in art. 7 of Civil Code of Ukraine.

Key words: legal custom, self-regulation, self-organization, contract, unilateral acts, property relationships. 